\title{
DESAFIOS DE LEITURA NUMA AULA DE LITERATURA ENTRE A HISTÓRIA, O MITO E A FICÇÃO
}

\author{
Luís Fernando Prado Telles \\ lf.telles@hotmail.com
}

Nada melhor do que um texto literário para iniciar uma aula de literatura, ei-lo:

Sozinho na noite da rua Augusto Gil, sentado no carro de motor desligado e luzes apagadas, o psiquiatra apoiou as mãos no volante e começou a chorar: fazia os possíveis para não emitir nenhum som, de modo que os ombros se lhe sacudiam como os das atrizes do cinema mudo, escondendo os caracóis e as lágrimas de abraço de um avô de barbas: Porra porra porra porra porra, dizia ele no interior de si mesmo, porque não achava dentro de mim outras palavras que não fossem essas, espécie de débil protesto contra a tristeza cerrada que me enchia. Sentia-me muito indefeso e muito só e sem vontade, agora, de chamar por ninguém porque (sabia-o) há travessias que só se podem efetuar sozinho, sem ajudas, ainda que correndo riscos de ir a pique numa dessas madrugadas de insónia que nos tornam Pedro e Inês em cripta de Alcobaça, jacentes de pedra até ao fim do mundo. (ANTUNES, 1997, p. 145.)

Este trecho é parte do parágrafo de abertura do décimo primeiro capítulo do livro Memória de Elefante de António Lobo Antunes. Neste seu romance de estreia, narra-se a vida de um médico psiquiatra, regressado da guerra colonial em Angola, onde servira como médico do exército, e que se encontra separado das filhas e da esposa. O romance é narrado em terceira pessoa (por um autor-narrador), mas sofre muitas interferências das falas/pensamentos do personagem protagonista, como é possível verificar 
no exemplo citado, em que se pode ver a alternância entre a terceira e a primeira pessoas do discurso. A presença da voz em terceira pessoa garante ao romance uma narrativa suficientemente clara e uma ordem temporal linear refletida na organização dos capítulos, os quais correspondem aos vários momentos de um período menor do que o de um dia da vida desse médico psiquiatra, que nos é apresentado em seu calvário de sofrimento permeado pelas lembranças da guerra e pela dor da separação da mulher e da filha. A passagem do tempo, no romance, éassinalada juntamentea uma mudança de cenário. Esta mudança temporal atrelada a uma mudança espacial confere à narrativa um tratamento episódico, já que os inícios dos capítulos introduzem índices espaciais que denotam mudança de cenário e que, consequentemente, indicam o deslocamento da personagem (a sua ação, portanto) e a passagem do tempo.

O índice espacial deste capítulo é a rua Augusto Gil, da cidade de Lisboa, na qual somos levados a ver a personagem estática, dentro de seu carro, e somos convidados a partilhar de seus pensamentos sobre o sofrimento causado pela separação da esposa. O sofrimento da solidão vem à tona curiosamente pela referência a um caso de amor português, o mito de Inês de Castro e de D. Pedro. De certo modo, o que ocorre nesta cena é a representação de um processo de recuperação subjetiva do imaginário cultural de um povo, imaginário este que surge com o poder de dotar o episódio de uma carga de significados construídos historicamente sobre o sofrimento em relação à separação da mulher amada. De certo modo, vemos a personagem lançando mão de seu referencial simbólico a fim de imprimir significado, de algum modo, ao sofrimento em que está imerso. Com esta referência, o caso da personagem protagonista é lançado ao campo de significação do mito e, com isso, demanda do leitor o agenciamento dos significados desse mito.

É quase certo que qualquer leitor diletante que tenha passado por alguma aula de literatura no colégio e que esteja com o Memória de Elefante nas mãos e depare com esta cena do capítulo onze irá se lembrar do caso, cantado por Camões, daquela que "depois de ser morta foi rainha” (Os Lusíadas, Canto III, 118). Com algum esforço poderá se lembrar do entrecho episódico que envolve o caso de amor entre Inês e D. Pedro e da vingança deste contra os assassinos da amada mandando-a coroar rainha. Esse leitor poderá lembrar ainda que o episódio cantado por Camões não se faz apenas como invenção, mas encontra registros na história, que se ancora num episódio que realmente aconteceu. Se esse leitor for um pouco mais curioso, poderá realizar uma breve pesquisa que o conduzirá a descobrir que, além de Camões, uma série de outros escritores, talvez menos populares e conhecidos, também já invocaram 
o caso de Inês de Castro e D. Pedro para contar suas histórias, tal como faz Lobo Antunes e, desse modo, conclua que se trata de apenas mais uma citação, mais uma repetição literária. Talvez esse leitor diletante e despretensioso se contente com essas lembranças e referências e pare por aí.

Contudo, para um leitor interessado na hermenêutica do texto, interessado em descobrir o que pode significar, no conjunto da narrativa, o discurso da personagem sobre as "madrugadas de insónia que nos tornam Pedro e Inês em cripta de Alcobaça, jacentes de pedra até ao fim do mundo", é inevitável o impulso pela busca de recuperação do sentido do caso de D. Pedro e Inês de Castro. Mas será essa uma tarefa possível?

$\mathrm{Na}$ busca pela reatualização desse sentido, o nosso leitor poderá encontrar relativa segurança nos relatos que procuram situar historicamente o fatídico caso de amor, os quais tentam, com frequência, explicitar os nexos causais do episódio e relacioná-los aos interesses políticos da época que teriam motivado o assassinato de Inês de Castro. Em geral, tais relatos baseiam-se nos cronistas dos reinos portugueses, tais como Rui de Pina e Fernão Lopes. António José Saraiva é um dos historiadores da literatura que nos apresentam esse quadro. Vejamos:

A história em si é que D. Pedro, sendo infante e casado, se enamorou de D. Inês de Castro, dama de companhia da sua esposa. Ela era bisneta de Sancho IV de Castela, filha bastarda de um poderoso fidalgo galego, D. Pedro Fernandes de Castro, o da Guerra, muito conhecido e privado do nosso rei D. Dinis. A esposa de D. Pedro, D. Constança Manuel, teve sucessivamente três crianças e Inês de Castro foi madrinha da segunda, ficando portanto a ser comadre do casal. Nesse tempo, o compadrio era um laço de parentesco religioso que impedia o casamento entre os compadres. Além disso, o infante D. Pedro era primo direto do pai de Inês, o que, segundo as leis canônicas, também impedia a união sexual. O Rei D. Afonso, pai de D. Pedro, que contrariava os amores adúlteros e incestuosos do filho com a fidalga galega, expulsou-a de Portugal. Ela acolheu-se no castelo de Albuquerque, perto da fronteira portuguesa, em casa de D. Teresa de Albuquerque, sua mãe adotiva, viúva de um filho de D. Dinis. [...] D. Constança teve um último filho, que veio a ser o rei D. Fernando, e morreu desse parto. D. Pedro estava livre; mandou vir D. Inês para junto dele e os dois apaixonados fizeram "maridança" publicamente. Do casal nasceram quatro crianças.

O regresso de D. Inês a Portugal era uma provocação para o rei que a pusera fora da terra. E tanto mais grave quanto o casal se instalou em Coimbra, a capital do Reino, no paço que a rainha D. Isabel, mulher de D. Dinis, construíra junto ao Mosteiro de Santa Clara para uso dos seus descendentes e respectivas esposas legítimas. Era natural que o rei se considerasse desfeitado e procurasse vingar-se. [...] O desfecho ocorreu quando D. Afonso IV, que estanciava perto de Coimbra, em Monte-mor-o-Velho, ouvidos os seus principais conselheiros, decidiu mandar matar Inês. Foi um golpe de surpresa. O infante D. Pedro tinha 
saído de Coimbra e, aproveitando a sua ausência, quando Inês estava só, sem defesa, o rei, acompanhado de gente armada, salteou as casas do Mosteiro de Santa Clara, onde ela pousava. Não nos custa a crer que o fizesse ao alvorecer, aproveitando o silêncio e o desamparo do crepúsculo matinal. Segundo o cronista Rui de Pina, na Crônica de D. Afonso IV, que provavelmente parafraseia uma crónica anterior de Fernão Lopes, Inês apareceu à porta suplicante com os três filhos, netos do rei. Ele esteve a ponto de se arrepender, mas deixou obrar os assassinos. [...]

A reação de D. Pedro foi a que era de esperar. Arremeteu de armas na mão contra o pai, reunindo gente de guerra de Portugal e de Galiza. Andou pelo Norte do País com um bando armado a devastar a terra.

Isso passava-se em 1355. Dois anos depois, D. Pedro subia ao trono. Os assassinos de Inês de Castro tinham fugido para Castela. Mediante negociações com o seu homônimo rei de Castela, D. Pedro conseguiu que lhe fossem entregues dois dos culpados, que mandou vir à sua presença para ele próprio interrogar. $\mathrm{O}$ terceiro procurado conseguiu fugir. A Pêro Coelho, refere o cronista, mandou tirar o coração pelo peito e a Álvaro Gonçalves pelas espáduas. Eram ambos fidalgos de alta categoria.

Passaram-se três anos. Em 136o, estando em Cantanhede, o rei fez juramento público e solene de que 'haveria sete anos pouco mais ou menos', em dia que não se lembrava, tinha casado com Inês de Castro e que desde então vivera com ela conjugalmente. Em vida de seu pai escondera este facto pelo receio que dele havia. Esta declaração foi registrada por notário e reiterada em Coimbra perante a corte reunida. Muita gente da corte ficou surpreendida e não acreditou. Como era possível D. Pedro não se lembrar do dia do seu casamento? A resposta do rei a esta dúvida foi provavelmente a construção dos túmulos de Alcobaça. (SARAIVA, 1996, p. 52)

A continuação dessa história, sobre o traslado dos restos mortais de Inês de Castro, o curioso leitor poderia acompanhar pela leitura das próprias palavras de Fernão Lopes, nas crônicas de D. Pedro, escritas quase cem anos depois do episódio (entre 1440 e 1450) e que viriam a ser impressas, em formato de livro, como o conhecemos, apenas em 1735, em Lisboa. É no capítulo quarenta e quatro dessas crônicas que Fernão Lopes discorre sobre Como foi trasladada Dona Ignez para o mosteiro de Alcobaça, e da morte de el rei D. Pedro. Assim escreve Fernão Lopes:

... sendo lembrado de honrar seus ossos [de Inês], pois lhe já mais fazer não podia, mandou fazer um moimento de alva pedra todo mui subtilmente obrado, pondo enlevada sobre a campa de cima a imagem dela com a coroa na cabeça, como se fora rainha; e este moimento mandou pôr no mosteiro de Alcobaça, não à entrada onde jaziam os reis, mas dentro da igreja, à mão direita, junto da capela mor. E fez trazer seu corpo do mosteiro de Santa Clara, onde jazia, o mais honrosamente que se fazer pode, [...]. E foi esta a mais honrosa trasladação que até aquele tempo em Portugal fora vista. Semelhavelmente mandou el-rei fazer outro tal moimento e tão bem obrado para si, e fê-lo pôr junto do seu dela, para quando sucedesse morrer o deitarem nele". (LOPES, 1968.) 
Depois de ler essa crônica de Fernão Lopes, o nosso leitor poderia, talvez, dar-se por satisfeito e retornar à leitura do romance de Lobo Antunes crente de que conseguira, de algum modo, recuperar o sentido original do episódio trazido à tona em Memória de Elefante. Teria, portanto, já, bastante informação para construir uma sua interpretação sobre o sentido desta intertextualidade, que poderia ser resumida ao coroamento de um amor que não pode ser concretizado em vida e que, portanto, ficou reservado à eternidade, figurada pelos monumentos dos túmulos, os quais seriam a concretização da vingança do casal.

Contudo, como o nosso leitor é curioso e tem tino de pesquisador, muito provavelmente procuraria saber um pouco mais, também, a respeito dos túmulos de Pedro e de Inês. O nosso leitor ficaria satisfeito em descobrir não apenas que os túmulos ainda existem na referida igreja de Alcobaça, mas que eles guardam significados importantes, já que descobriria também que nos próprios túmulos D. Pedro mandou esculpir, à época, em baixo-relevo, a história da sua paixão.

Agora o nosso leitor parece ter chegado à fonte primeira de informação do episódio, já que as histórias esculpidas seriam as provindas do testemunho de seu próprio protagonista, D. Pedro. Numa breve pesquisa, o leitor poderia tomar contato com as belas imagens dos túmulos e, intrigado em desvelar o sentido daquela profusão de esculturas em baixo-relevo, talvez procurasse auxílio em algum historiador da arte e da literatura e, se tivesse sorte, encontraria a explicação de António José Saraiva, que assim os apresenta:

O túmulo de Inês assenta nos lombos de seis animais que são quadrúpedes com rosto humano. As caras desses quadrúpedes agachados são retratos individuais e personalizados; um dos homens tem barba e os outros cara rapada; alguns têm cabelo, os outros são calvos. Quem são os retratos? Na época em que foram esculpidos os túmulos, toda a gente os reconhecia. Eram certamente os intervenientes no assassínio de Inês, quer como executores, quer como conselheiros. Uns tinham sido já mortos, como Álvaro Gonçalves e Pêro Coelho, outros andavam fugidos. O que nos impõe esta identificação é que o túmulo de D. Pedro também assenta sobre quadrúpedes, mas, neste caso, meros leões decorativos. D. Pedro quis que, para toda a eternidade, os assassinos carregassem o peso da sua culpa e que as gerações presentes e as futuras conhecessem as suas caras.

Os túmulos estão profusamente esculpidos e lavrados.

O do rei narra a história de São Bartolomeu, um rei que foi apóstolo de Cristo e lutou contra os ídolos, tendo por isso sido esfolado, morto e descabeçado, e que depois de morto, pegando na própria pele e na própria cabeça como quem pega num saco, se apresentou ao rei que o matara. Quem sabe se não há nesta escultura uma alusão à sobrevivência espiritual da que "depois de ser morta foi rainha?" (SARAIVA, 1996, p. 52) 
A redenção do casal desfeito em vida aparece na cena do Juízo Final que está representado na parte frontal do túmulo de Inês:

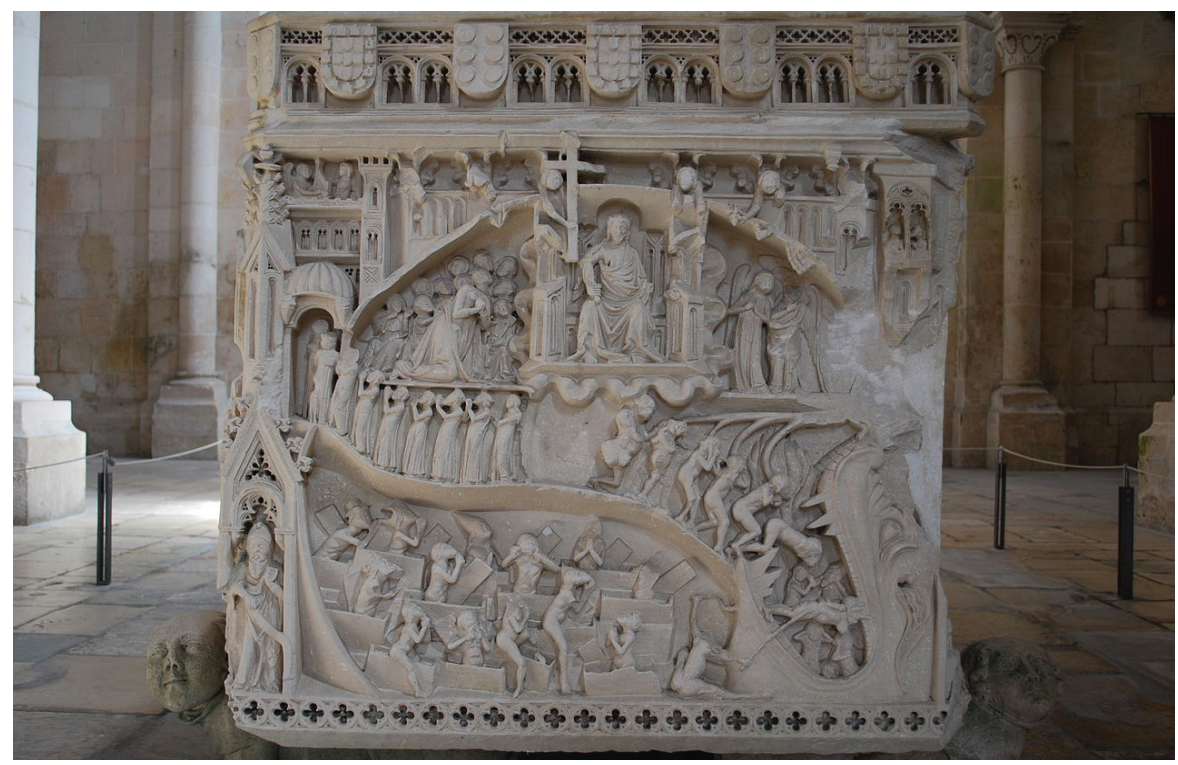

Conforme descreve Saraiva, nesse baixo-relevo, podemos ver que

Os mortos de várias categorias hierárquicas, desde o papa aos simples fiéis, abrem a campa dos túmulos perante o Deus-Juiz, assistido da Virgem e dos seus anjos e santos. Os justos, com túnicas compridas e mãos postas, encaminhamse pela direita para a porta do Paraíso; os condenados, nus e com gestos descompostos, vão, por um plano inclinado, cair nas goelas de um monstro, onde são atormentados por Diabos, no canto esquerdo. O paraíso tem zimbórios que lembram gomos de laranja, como as guaritas da Torre de Belém, torres como as da Praça da Senhoria de Florença. A uma janela geminada que anuncia o manuelino divisam-se dois vultos de bem-aventurados que mereceram o Paraíso: são Pedro e Inês. Os pecadores subiram ao Céu. (SARAIVA, 1996, p. 54)

Se quisesse, o nosso intrigado leitor poderia também acompanhar toda a interpretação feita por António José Saraiva sobre o baixo-relevo que se encontra esculpido na parte frontal do túmulo do próprio D. Pedro, em que se vê uma rosácea, na qual se distinguem a roda da vida e a roda da fortuna: 


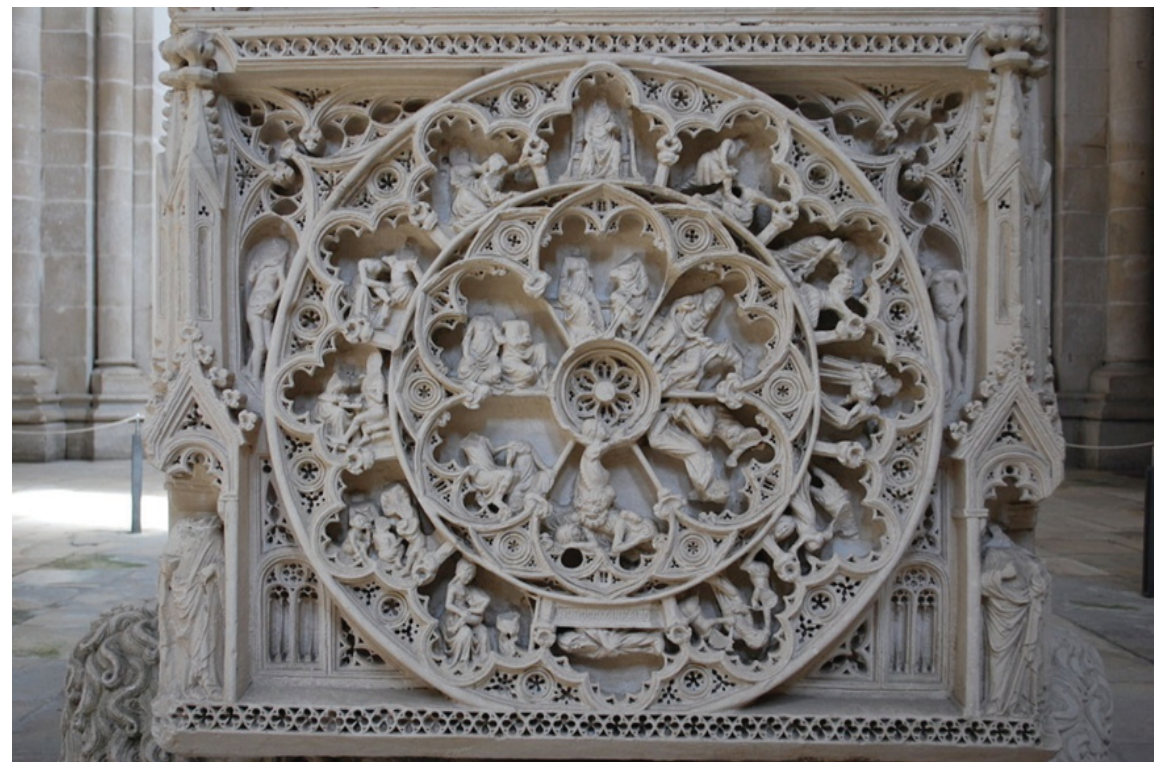

Por essa escultura, demonstra Saraiva que D. Pedro procurou contar toda a sua vida e é justamente no final dessa narrativa imagética que podemos ver que o rei, no extremo inferior da rosácea, está deitado no caixão, onde seria possível ler, em latim, o seguinte dito: "Aqui espero o fim do mundo”. Acompanhemos a hermenêutica proposta por Saraiva:

São três circunferências concêntricas, que definem três espaços; no primeiro e no segundo a contar de fora há figuras humanas; no círculo mais interior já não há história, mas só as pétalas de uma flor dispostas circularmente à volta de um centro. As figuras humanas constituem cenas sucessivas. A nosso ver, a rosácea deve ler-se em dois diferentes sentidos: circularmente, andando à volta, e seguindo as fases históricas evocadas nos baixos-relevos; e verticalmente, de cima para baixo, seguindo o diâmetro que divide ao meio os círculos. Este diâmetro separa as cenas felizes, à direita (esquerda do observador), das cenas trágicas, historiadas à esquerda. Cenas históricas e realistas enchem os dois círculos concêntricos, à volta de um círculo interior, vazio de história e de tempo.

A leitura vertical seguindo o diâmetro é mais simbólica do que histórica: ao alto, no círculo exterior, um rei em majestade no trono, o próprio Pedro em vida; no círculo médio, um casal sentado, provavelmente Pedro e Inês no apogeu que não tiveram. Em baixo, no mesmo círculo exterior, o cadáver de Pedro estendido no túmulo, sobre o qual, no círculo médio, se vê sair uma figura nua que se liberta da carcaça terrena, que parece a pele de um monstro que tem por cabeça uma máscara de teatro antigo e que se apoia sobre dois corpos prostrados. Esta figura extravasa o círculo intermédio e entra parcialmente no círculo interior, onde (como vimos) não há história nem viventes, o círculo de vida sobrenatural. Supondo que é a alma de D. Pedro elevando-se para o Paraíso por sobre o seu cadáver. 
Em resumo: na zona exterior, ao alto do diâmetro, o rei em majestade e em baixo o rei morto; na zona média, ao alto, o sonho não realizado da partilha do trono com D. Inês e, em baixo, a alma do rei ascendendo ao Paraíso, entrando parte dela já no círculo interior.

Se considerarmos agora as figuras das circunferências da direita para a esquerda (esquerda para a direita do observador), na zona média temos, no lado direito do diâmetro, D. Pedro acariciando Inês no ombro; Pedro e Inês juntos e enlaçados numa cena de ternura; e, como já vimos, Pedro e Inês no trono (como ele sonhou); depois, no lado esquerdo do mesmo diâmetro, o rei D. Afonso dando com o índex a ordem de expulsão a Inês e uma outra cena que representa dois corpos em movimento, numa atitude indecifrável. Essa mesma sucessão de alegria e tristeza repete-se na seção exterior do círculo. A primeira figura à direita representa Inês com o primeiro filho ao colo; a segunda, os três filhos do casal, com os pais em segundo plano; a terceira, Pedro e Inês jogando o xadrez, cujo tabuleiro se apoia nos joelhos de ambos; na quarta, Inês faz carícias com as mãos nas coxas de Pedro, que tem a perna traçada, e, finalmente, neste mesmo lado direito vemos uma figura de homem de gatas e por detrás dele uma mulher batendo-lhe com a mão na anca. São tudo cenas da vida familiar e íntima do casal. Saltando por cima do rei no apogeu (que está, como vimos, no alto), entramos na zona esquerda. Aí vemos principalmente um homem de saiote que põe o pé em cima de uma mulher derrubada; depois a mulher parece ter contra-atacado: está de pé, agarra o homem pelo cabelo, arrasta-o e põe-lhe o pé em cima da perna. Isto parece significar uma luta corpo a corpo entre Inês e seu assassino. Em seguida, outro homem, de trajo comprido, agarra Inês pelo cabelo e torce-lhe o pescoço. E eis que, no episódio seguinte, a cabeça de Inês está por terra; o homem de saiote voltou e degolou-a. Inês desaparece da cena. A seguir vemos um homem de barba longa agarrado por dois carrascos, um dos quais lhe enterra o punhal no peito. Podemos imaginar que é o castigo do assassino de Inês, a não ser que se trate da representação simbólica da dor que Pedro sofreu com a morte de Inês. Agora, o rei, no extremo inferior da rosácea, está deitado no caixão, como já vimos, o caixão onde se lê: Aqui espero o fim do mundo. (SARAIVA, 1996, P. 54)

Apesar de ter reconhecido na inscrição tumular "Aqui espero o fim do mundo" a fonte do diálogo intertextual da frase de António Lobo Antunes que encerra o trecho citado de início "jacentes de pedra até ao fim do mundo", a essa altura o nosso esforçado leitor já deve ter percebido que aquela tarefa pela busca de recuperação do sentido original do caso de Pedro e Inês talvez seja mesmo uma tarefa impossível.

Nesse momento, o leitor já teria dado conta, por exemplo, de que a versão do caso que é relatado por Fernão Lopes e que é, de certo modo, também recuperada por Camões, difere da que é apresentada pela história que é retratada pelas esculturas feitas em baixo-relevo a pedido do próprio D. Pedro. Nesta versão imagética, diríamos, o que ganha relevo é a dimensão sagrada de uma união que se prolonga para além da morte e que é sacramentada no Juízo Final. Há, também, uma 
forte representação maniqueísta, em que os culpados são terrivelmente punidos. Não há, portanto, como o há nos relatos de Fernão Lopes ou nos versos de Camões, um abrandamento da culpa de D. Afonso IV, o qual, já arrependido da decisão de matar Inês, teria transferido aos conselheiros a responsabilidade por tal ato.

A essa altura o nosso astuto leitor já deve ter desconfiado que a versão do próprio D. Pedro é já uma interpretação dos fatos dos quais ele mesmo foi o protagonista e, o mais curioso, é que para eternizar a sua história, D. Pedro utiliza-se de outras narrativas, as bíblicas, para, de forma indireta, contar o seu caso de amor. Ou seja, o próprio D. Pedro utilizou-se da estrutura mítica para contar a sua história (por meio da analogia com outras histórias: a vida de São Bartolomeu, o Juízo Final e a Roda da Vida e da Fortuna) e, assim, contribuir para que ela se transformasse num mito também.

Diante disso, nosso leitor já deve ter percebido que a realidade factual é sempre apreendida pela mediação de uma construção simbólica e que, portanto, a história, mesmo que baseada em fatos e narrada por aquele que a vivenciou, nunca deixa de ser uma construção simbólica, também. O episódio histórico de Inês de Castro e de D. Pedro, portanto, é o resultado de interpretações (construções textuais), seja do próprio D. Pedro, por meio das esculturas (interpretadas, aqui, em primeira mão, pelo historiador António José Saraiva), seja dos cronistas do reino tais como Fernão Lopes ou de poetas como Camões.

$\mathrm{O}$ arguto leitor também já deve ter notado que a história, em sendo uma construção textual, carrega consigo as marcas de seu tempo e faz revelar os pontos de vista e interesses (explícitos ou implícitos) daqueles que as enformam. Deve ter pensado o nosso inteligente leitor que o fato de não ser possível recuperar um sentido original de uma história ou de um mito não deve ser motivo de desespero, muito menos significa que os sentidos que podem ser depreendidos das várias interpretações ou apropriações da história não possam ser válidos, ou tenham de ser desconsiderados por não serem portadores de uma verdade original. $\mathrm{O}$ nosso leitor descobrirá, pelo contrário, que a riqueza do mito do amor de Pedro e Inês reside justamente na capacidade de ser reatualizado, ao longo do tempo, ou seja, de permanecer na medida em que é reinterpretado.

É com o ânimo renovado que o leitor passará a olhar para outros momentos da história da literatura portuguesa e constatará que cada escritor e cada época ofereceu uma forma nova de retomada dessa história, agora, já transformada em mito.

Verá, por exemplo, que Garcia de Resende (1470-1536) dá voz, em suas Trovas à morte de D. Inês de Castro (utilizando-se da estrutura do 
verso da cantiga de amigo) à própria Inês, que canta o seu infortúnio e enaltece, também, o arrependimento do rei. Verá ainda que mesmo antes de Camões eternizar o amor de Pedro e Inês, como parte de sua épica, no Canto III de Os Lusíadas, António Ferreira já o havia colocado em formato clássico, o da tragédia.

Nesta obra, intitulada Castro, o que ganha relevo, inclusive, não é o desfecho trágico, o clímax não é o assassinato, mas os fatos que antecedem o desfecho, sendo o momento alto da tragédia o penúltimo ato, o quarto, em que se representa o diálogo entre Inês e D. Afonso IV, pouco antes da execução, em que ela o convence a absolvê-la da pena de ter de morrer, sendo assim aclamada como uma espécie de mártir pelo rei: "Ó mulher forte!/Venceste-me, abrandaste-me. Eu te deixo./Vive, em quanto Deus quer". O rei D Afonso IV, por seu turno, é aclamado pelo coro da tragédia como piedoso, o qual faz recair toda a culpa do assassinato de Inês no carrasco: "Rei piadoso, Vive tu, pois perdoas; morra aquele/ Que sua dura tenção leva adiante." (FERREIRA, 1939. p. 219)

Com um pouco mais de pesquisa e paciência, o nosso leitor curioso descobriria que esse mito não saltou dos relatos da idade média ou das formas clássicas de um António Ferreira ou de um Camões diretamente para as páginas do romance de Lobo Antunes. Esse leitor verá que esse mito de amor atravessou outros séculos, assumindo outras formas e, obviamente, outros significados. No século dezenove, por exemplo, Afonso Lopes Vieira (1878-1946) o colocaria em formato de soneto (Linda Inês) e cantaria esse amor já embebido pelas lunetas do romantismo, exaltando a pureza do amor espiritual, a memória e, sobretudo, a saudade, que já é anunciada logo na primeira estrofe: "Choram ainda a tua morte escura/ Aquelas que chorando a memoraram;/As lágrimas choradas não secaram/ Nos saudosos campos da ternura." (VIEIRA, 1918, p. 123-4.)

Ainda no mesmo século XIX, o nosso leitor poderá testemunhar a elevação do mito do amor de Inês e D. Pedro a símbolo da identidade nacional portuguesa personificada pela saudade, a que se mostra eternizada nas duas personagens. Na peça do simbolista António Patrício (1878 -1930), intitulada Pedro, o Cru, as personagens não sentem apenas saudade, mas esta passa a ser personificada, Pedro e Inês são a própria saudade:

Vivi um ano assim, do teu martírio. O teu sangue, amor, era o meu vinho. A tua morte, Inês, foi o meu pão. Fugia ao sol: a luz envenenava-me. Queria estar só, bem só, murado em mim: - cavava no silêncio um fojo escuro para poder cevar na minha dor. O meu crânio era uma câmara de tortura: - viviam lá um carrasco e os assassinos. E o carrasco era eu, era o teu Pedro. Oirava de pensar... de sentir sangue... Para ver se assossegava, ia montear. (...) Era um lobo o teu Pedro: era uma hiena. Mas um dia, "Alguém” desceu ao fojo: “-Alguém” que era da morte e 
além da vida. E eu vi a Saudade ao pé de mim. Nunca mais me deixou: vivo com ela. Fez-se em mim carne e sangue. Fez-se Inês. Por isso sabes toda a minha vida. Por isso eu sei a morte como tu. Sou o homem que viveu a vida e a morte: sou o homem-Saudade, o rei-Saudade ... Sou o rei ... o rei do maior reino... do reino que me deste, minha Inês... Duas vezes Rainha! ... Santa! Santa! Se eu estou aqui ao pé de ti - tudo foi bom!... A minha dor, Inês, beijo-a nos olhos!... beijo-a como beijei a tua boca ... como - cerrando os olhos na saudade - beijei, beijei, beijei a tua alma... (PATRÍCIO, 1982. P. 167-8)

A essa altura do século dezenove o nosso leitor já deve ter percebido, também, que, para a literatura, a questão de se buscar o sentido original não é uma questão fundamental e que as provas sobre o acontecimento histórico que deu azo às várias construções têm uma importância relativa, já que o que dá sustentação e longevidade ao mito é a capacidade de ser recuperado em vários formatos e de gerar novos sentidos, em cada momento histórico que é reatualizado.

No caso de António Patrício, por exemplo, ocorre uma espécie de reversão de valores, o que era tido como originalmente negativo, a morte de Inês, passa a ser visto sob um ponto de vista positivo, transforma-se em valor máximo, já que é a responsável por instaurar um novo reino, o reino da Saudade. De certa maneira, nesta peça, o episódio é visto como sendo responsável por fundar uma certa identidade portuguesa forjada pela ideia de saudade. Ao analisar o que chama de "tradição inesiana", Osakabe (1991) aponta para o fato de que nas primeiras produções literárias sobre o caso, as medievais e as renascentistas, a tônica incide sobre os eventos que antecedem a morte de Inês (o encontro amoroso, a conspiração dos cortesãos, o diálogo entre Inês e D. Afonso IV e a execução), ficando reservados a comentário menor os eventos post-mortem. Há, portanto, nos textos iniciais, um impacto maior do macabro. Ao contrário das iniciais, contudo, a maioria das outras obras que se seguiram focaram o interesse na investigação do sentido mais profundo do caso, levando em conta sobretudo as decorrências da morte no tipo de comoção provocada no amante e na própria coletividade. $\mathrm{O}$ interesse inicial pelo macabro vai se convertendo numa reconfiguração sublime do mito. No que se refere a esse aspecto, Osakabe considera ser modelar o caso da peça de António Patrício, pois esta "consagra em definitivo a interposição do caso Pedro e Inês com conteúdos medievais e o conteúdo português da saudade” (1991, p. 113).

$\mathrm{O}$ fato de o mito de $\mathrm{D}$. Pedro e Inês ter se transformado numa espécie de herança e de saldo positivo para a história do imaginário português resulta em outros caminhos que não o da própria afirmação direta do mito, mas de uma afirmação negativa por meio do efeito irônico da paródia, por exemplo. 
Isso é o que poderá comprovar o nosso leitor quando, ao sair do século XIX, voltar seus olhos para as apropriações do mito no século XX; certamente, poderá divertir-se e será conduzido a pensar o mito de Inês e de D. Pedro de uma perspectiva totalmente deslocada das que se afirmaram ao longo da história se chegar às suas mãos o conto Teorema de Herberto Helder, já de 1963.

A história da vingança contra o crime da morte de Inês de Castro ganha neste conto um ponto de vista curioso por ser narrada por um dos assassinos de Inês, Pero Coelho. O narrador relata a sua própria morte, descreve a sua visão do episódio a partir dos olhos de sua cabeça já decapitada e nos apresenta a cena de D. Pedro comendo o seu coração. O mais curioso é que o narrador do conto parece ter consciência da importância histórica da morte de Inês para a manutenção do amor eterno de D. Pedro e, inclusive, para a manutenção do mito e da saudade eterna do povo português, como é representada por António Patrício, por exemplo. Neste caso, a lógica da história se inverte e o vilão da história, o assassino Pero Coelho, se converte em herói, e é assim que se entende ao narrar a sua história. Vejamos:

El Rei D. Pedro, o Cruel, está na janela sobre a praceta onde sobressai a estátua municipal do marquês Sá da Bandeira. Gosto deste rei louco, inocente e brutal. Puseram-me de joelhos, com as mãos amarradas atrás das costas, mas levanto um pouco a cabeça, torço o pescoço para o lado esquerdo, e vejo o rosto violento e melancólico do meu pobre Senhor. (...) O rei olha para mim com simpatia. Fui condenado por ser um dos assassinos da sua amante favorita, D. Inês. Alguém quis defender-me, dizendo que eu era um patriota. Que desejava salvar o Reino da influência espanhola. Tolice. Não me interessa o Reino. Matei-a para salvar o amor do rei. D. Pedro sabe-o.

- Senhor, - digo eu - agradeço-te a minha morte. E ofereço-te a morte de D. Inês. Isto era preciso, para que o teu amor se salvasse.

Matei por amor do amor (...). (HELDER, 1975. pp. 368 - 370)

Este conto é um excelente exemplo de recuperação paródica do mito, já que, segundo Gobbi, "a paródia, utilizando-se de sua principal estratégia retórica, a ironia, não simplesmente afronta o mito, mas exacerba-o ou desloca-o de tal maneira, usando os mesmos truques que o configuraram (...), e isso acaba por revelar os mecanismos de construção do próprio mito..." (2011, p. 43). Nesse sentido, implica considerar que, ao imitar textos do passado, mesmo com diferença crítica, a paródia os reforça.

A partir disso, é possível reter uma característica importante do mito: a de ter de equilibrar-se no paradoxo da permanência e da mudança, uma vez que toda reatualização seria, já, uma ressignificação. Assim, se, por um lado, o discurso religioso, por exemplo, que visa ao sagrado, 
lutaria por uma permanência do sentido original do mito por meio do rito, conforme nos explica Mircea Eliade (1999); o discurso literário, por sua vez, seria responsável pela permanência do mito em seu processo contínuo de recuperação ao longo da história, mas pela via da mudança, da ressignificação, quer seja pela busca da reafirmação de certo sentido tido como original, quer seja para enriquecer ou mesmo para problematizar tal sentido, inclusive pela via da reversão, como a paródia o faz.

Se tivesse um pouco mais de paciência, o nosso leitor poderia passear por outras obras e outras apropriações literárias do século XX, tais como, por exemplo, as Adivinhas de Inês e Pedro, romance de Agustina Bessa Luís, de 1983; mas acredito que, apesar de persistente, nosso leitor já deva estar cansado e se perguntando:

Mas terá valido a pena todo esse percurso pelo mito de Inês de Castro e D. Pedro?

Tudo vale a pena se...

Bem, antes que alguém se arrisque a completar o verso e coloque um fim nessa história toda, vejamos um dos sentidos que pode assumir o mito reatualizado nesse texto de Lobo Antunes, no contexto em que se insere a sua obra, no pós 25 de abril.

O poeta e ensaísta português Norberto do Vale Cardoso, ao estudar as relações entre as Cartas de Guerra de Lobo Antunes e os seus romances iniciais, detecta uma incidência constante de trechos dessas cartas no corpo da narrativa dos romances, em especial trechos compostos a partir de uma linguagem cifrada, ou, como ele diz, criptografada. Este tipo de linguagem teria sido usada por Lobo Antunes para se proteger do controle a que eram submetidas as suas correspondências. Conforme diz o ensaísta, esse controle levava o seu emissor a uma autocensura prévia à censura externa, a qual se aplicava não apenas às cartas dos soldados, como também às mensagens dos soldados ao canal público de televisão ou às mensagens que chegavam por rádio.

Um dos elementos que serviam como uma espécie de código entre Lobo Antunes e sua esposa era a referência a eles próprios como sendo Pedro e Inês. Cardoso anota o fato de Lobo Antunes sempre encerrar as cartas de guerra dirigidas à esposa com a frase que aparece inscrita no túmulo de D. Pedro, conforme vimos, "até o fim do mundo"; frase esta que encerra o trecho citado por nós no início e que aparece mais de uma vez em Memória de Elefante, como, por exemplo, no seguinte trecho: "GTS disse-lhe sem falar sentado à secretária do hospital, recuperando o morse através do qual comunicavam sem serem entendidos de mais ninguém, GTS até ao fim do mundo, meu amor, agora que somos já Pedro e Inês nas criptas de Alcobaça à espera do milagre que há-de vir." (ANTUNES, 1997. p. 59) 
Essa referência ao mito de Inês de Casto e D. Pedro no romance de Lobo Antunes, atualizada dentro do contexto da guerra colonial em Angola, da qual participou o autor, e da ditadura Salazarista, ganham novo sentido. $\mathrm{O}$ mito pode ser reatualizado, agora, sob outra ótica, visto que não é ingênua ou gratuitamente recuperado, mas serve, inclusive, para traduzir a densidade dramática da separação amorosa e o nível de sofrimento psicológico por que passa a personagem protagonista. Uma hermenêutica possível deste mito recorrente em Lobo Antunes nos oferece o próprio Cardoso, ao pensar a prosa ficcional do autor em relação aos textos de suas cartas:

Ora, o que vemos na Memória de Elefante é uma atualização do tempo da guerra, pois, no hospital, os sucessivos flashbacks acabam por conduzir o psiquiatra à onipresença do passado no seu presente, lembrando os códigos de produção do texto e distinguindo receptor de destinatário e leitor comum de leitor ideal. Deste modo, a presença da censura é tida como infrutífera para a sua relação e para o condicionamento do texto. Reparemos que a frase final [do trecho de Memória de Elefante citado no início] é um claro exemplo da encriptação do texto, pois se, por um lado, denota o seu amor como proibido, condenado pelo destino, que separou os amantes, por outro conota este amor como invencível. Como Pedro e Inês que são, os dois amantes, enclausurados "nas criptas" (textos-monólogo), veem-se sem vida, mas "à espera do milagre que há de vir” depois da guerra. Então, a escrita/carta, mesmo denunciando o encerramento dos amantes nos seus túmulos, declara que é através dessa criptografia que se libertarão. As "criptas de Alcobaça” não fecham o texto, antes o tornam em si mesmo numa cripta que só o romance parece ser capaz de abrir. (...)

De fato, se, nas Cartas, António e Maria José se comparam a Pedro e Inês, tal fato deve-se à separação forçada dos dois amantes por um regime ditatorial que é, afinal, um Pai ideal que a tudo se impõe. Assim, temos, nas Cartas e no romance posterior, a denúncia de que o Estado era, naquele tempo, como o "fraco Rei", que "faz fraca a forte gente" d' Os Lusíadas (III-139).

A proibição do amor, anterior à revolução, terá tido repercussões no tempo posterior, pois os amantes, separados pela guerra, não mais conseguem reconstruir a vida interrompida, ficando cada um encerrado no seu túmulo. Ao fazer reemergir (pela carta integrada no romance) a declaração de amor e a denúncia do autoritarismo anterior, Lobo Antunes leva-nos a inferir que esse tempo não pode ser esquecido e que o milagre esperado nas Cartas nunca chegou a acontecer no tempo dos romances. Então, o tempo posterior leva a uma reconstrução do anterior, denunciando que essa guerra foi o algoz de toda uma geração e que é necessário compreender o salazarismo em vez de o recalcar. O Estado Novo, como Pai ideal, foi menos humano que a loba que criou "os irmãos que Roma edificaram" (Os Lusíadas, III-126). Assim como a morte de Inês de Castro atentara ao código cavaleiresco, pois os carniceiros pretendiam ser cavaleiros, também a guerra, com a censura, atentara ao código da comunicação, exigindo os silêncios, as omissões e as autocensuras.

Do mesmo modo, devemos aqui entender que o tempo posterior à guerra (com 
os ideais que levaram à revolução e à democracia) não foi capaz de sarar essas feridas. Este aspecto leva o protagonista dos primeiros romances a rejeitar tanto o regime anterior como o novo tempo. Então, o sujeito dos romances tornar-se-á uma espécie de LOBO, mas será menos fera que os humanos que o levaram a essa identidade animalizada. Como é incapaz de esquecer, a Memória de Elefante devolve-o à guerra e à necessidade de agir como D. Pedro I após a morte de Inês de Castro. O psiquiatra que vemos nos primeiros romances, sobretudo n' Os Cus de Judas, será o Justiceiro, o "castigador" que persegue e retira o coração dos "homicidas" (III-137), que, para o protagonista da Memória, de [O Cus] de Judas e do Conhecimento [do Inferno] parecem ser todos os que não fizeram a Guerra Colonial. Esta "vingança" exorciza os fantasmas da guerra e narra as sequelas que esta deixou nos soldados portugueses.

(CARDOSO,2008. p. 2)

É interessante perceber, pela hermenêutica apresentada, que a menção ao mito pela narrativa de Lobo Antunes convoca uma atitude interpretativa não apenas de recuperação dos sentidos anteriores do mito, mas, inclusive, convoca o leitor para um entendimento do momento histórico do próprio discurso que promove a reatualização. Aqui talvez esteja mesmo o ponto da questão, a tomada de consciência de que ficção, mito e história convergem para um mesmo ponto quando pretendemos extrair deles algum sentido: a linguagem.

No exemplo interpretativo apresentado, é clara a aceitação da chave metafórica que leva à comparação entre o despotismo do rei Afonso IV e o sistema ditatorial português do salazarismo, o qual, juntamente com a guerra colonial em Angola, contribuem para colocar a personagem protagonista de Memória de Elefante e a sua esposa evocada pelo discurso deste na mesma posição de $\mathrm{D}$. Pedro e Inês de Castro. O que chama a atenção desse exercício de leitura é justamente o fato de o procedimento utilizado para extrair a hermenêutica do texto de Lobo Antunes para interpretar o mito de Pedro e Inês dentro da prosa de ficção aproximar-se do que vimos ser utilizado para interpretar as próprias narrativas expostas em baixo-relevo nos túmulos de Alcobaça, ou seja, a via da analogia entre narrativas.

Outras interpretações poderiam emergir pela utilização da analogia, inclusive propondo a relação do tempo histórico retratado no romance com outros tempos de outras reatualizações desse mito aqui vistas. Isso dependeria da disposição de leitura, é claro. Mas, nesse momento, possivelmente o leitor que nos acompanhou até aqui possa já estar cansado, de fato, e talvez esteja julgando que o saldo da fatura dessa longa caminhada possa não lhe ter dado grandes lucros para a leitura do romance que tem em mãos. 
Se esse leitor nos indagasse, provavelmente diríamos a ele que o que possa ter valido a pena não tenha sido necessária e exclusivamente o ponto de partida (que também foi o nosso ponto de chegada), mas o caminho percorrido propriamente dito. Este, sim, parece ter valido para percebermos, juntos, que, apesar de teoricamente distintos, mito, história e ficção se constituem simbolicamente e demandam uma tomada de consciência desse processo de construção, cuja explicitação é característica marcante de nossa literatura contemporânea, da qual a narrativa de António Lobo Antunes é uma representante exemplar.

Assim, se é verdade que "um dos papéis fundamentais da escola é tornar as novas gerações capazes de compor vínculos com o passado", isto é, "dotá-las de instrumentos de apropriação do passado no que ele encerra de outro, de diferente em relação à contemporaneidade" (FRANCHETTI, 2002, p. 78); igualmente verdade é o fato de que a aula de literatura se apresenta como o espaço privilegiado para a escola desempenhar esse papel de um modo singular. Principalmente pelo fato de que nela o leitor deve ser constantemente convocado pelo texto literário a atuar no processo de construção de sentidos, sendo obrigado a sair da posição passiva, de simples recebedor de conteúdos, e assumir a de sujeito de seu processo de conhecimento. Ao ser colocado pela literatura no terreno que se move entre o mito, a história e a ficção, o leitor é levado a perceber que os caminhos de leitura que o fazem estabelecer vínculos com o passado dependem sempre da tecitura da linguagem que emana de um lugar histórico marcado e que faz com que os sentidos sejam produzidos e aceitos de modo contingencial. Essa tomada de consciência parece ser fundamental para que a escola permita, conforme argumenta Franchetti, «a criação e análise dos vínculos do presente com a tradição literária de língua portuguesa e, em última instância, com a tradição dos temas e questões que foram construindo, ao longo dos séculos, a autorrepresentação, ainda atuante, a que chamamos Ocidente." (2002, p. 78)

Por fim, poderíamos dizer ao nosso leitor que, depois desse percurso de leitura, estaria suficientemente vacinado contra a busca ingênua pela verdade da história ou contra a repetição vazia do mito. Por outro lado, esperaríamos que tivesse aprendido, também, que as citações e referências intertextuais da literatura (principalmente a contemporânea) não permitem que o leitor saia dela impune, sem carregar em seus ombros a tarefa e a responsabilidade de reconstituição dos mitos e da própria história. 


\section{REFERÊNCIAS}

ANTUNES, António Lobo. Memória de Elefante. Lisboa, Publicações Dom Quixote, 1997.

BESSA-LUÍS, A. Adivinhas de Pedro e Inês. Lisboa: Guimarães \& C. a , Editores, 1983.

CAMÕES, Luís Vaz de. Os Lusíadas. Canto III (118 a135). Obras Completas. Rio de Janeiro: Nova Aguilar, 1988.

CARDOSO, Norberto do Vale. Epístola de Judas aos Lusíadas: das Cartas aos romances de António Lobo Antunes. Revista Agulha. Fortaleza/São Paulo, nov. dez. 2008. http:// www.revista.agulha.nom.br/ag66antunes.htm

ELIADE, Mircea. O Sagrado e o Profano. São Paulo: Martins Fontes, 1999.

FERREIRA, António. Castro. Lisboa: Editora Ulisseia, 1998.

FRANCHETTI, Paulo. O cânone em língua portuguesa: algumas reflexões sobre o ensino de literatura brasileira e portuguesa no Brasil. Voz Luzíada. No. 18, São Paulo, 2002. pp. $71-78$.

GOBBI, Márcia Valéria Zamboni. A ficcionalização da História: mito e paródia na narrativa portuguesa contemporânea. São Paulo: Unesp, 2011.

HELDER, Helberto. Teorema. In: MOISÉS, Massaud. (Org.). O conto português. São Paulo: Cultrix/Editora da Universidade de São Paulo, 1975.

LOPES, FERNÃO. Crônicas de El Rei D. Pedro. In: Crônicas. Rio de Janeiro: Agir, 1968.

OSAKABE, Haquira. A Pátria de Inês de Castro. IN: IANNONE, C. A.; GOBBI, M. V. Z.; JUNQUEIRA, P. S. (ORG.). Sobre as naus da iniciação: estudos portugueses de literatura e história. São Paulo: Ed. UNESP, 1991.

PATRÍCIO, António. Pedro, o Cru. Teatro Completo. Lisboa: Assírio e Alvim, 1982.

RESENDE, Garcia de. Trovas à morte de D. Inês de Castro. In: Moisés, Massaud. A literatura portuguesa. São Paulo: Editora Cultrix, 1999.

VIEIRA, Afonso Lopes. Cancioneiro de Coimbra. Coimbra: França Amado, 1918. Disponível em: http://www.angelfire.com/pq/unica/il_alv_1918_cancioneiro_coimbra.htm

\section{REFERÊNCIAS DAS IMAGENS:}

Julgamento Final:

http://commons.wikimedia.org/wiki/File:Mosteiro de Alcoba\%C3\%A7a T\% $\% \mathrm{C}_{3} \%$ BAmulo de In $\% \mathrm{C}_{3} \%$ Ags de Castro - Dia do Julgamento.jpg?uselang=pt-br

Roda da vida e da fortuna:

http://commons.wikimedia.org/wiki/File:Mosteiro_de_Alcoba\%C3\%A7a_T\%C3\%BAmulo_ do Pedro I - Roda da Fortuna.jpg 